\author{
Magdalena MaciejewsKa, GRAŻYnA ZGÓRKA \\ Katedra i Zakład Farmakognozji z Pracownia Roślin Leczniczych, \\ Uniwersytet Medyczny w Lublinie, \\ Chodźki 1, 20-093 Lublin, \\ E-mail: magdalena.maciejewska@umlub.pl, \\ gzgorka@pharmacognosy.org
}

\title{
RODZAJ TRIFOLIUM L. (KONICZYNA) JAKO NOWE ŹRÓDŁO FITOSKŁADNIKÓW O ANTYBIODEGENERACYJNYCH WŁAŚCIWOŚCIACH
}

\section{WSTEP}

Rodzaj Trifolium L. należy do najbardziej rozpowszechnionych taksonów, reprezentujących rodzinę Fabaceae (bobowate), dawniej Leguminosae (motylkowe). Obejmuje on ponad 240 gatunków, zasiedlających obszary strefy subtropikalnej i umiarkowanej obu półkul. Największą różnorodność koniczyn odnotowuje się jednakże w trzech regionach geograficznych: basenie Morza Śródziemnego, przeważającej części Ameryki Północnej ( $z$ wyjątkiem strefy południowej) i górskich obszarach wschodniej części Afryki.

Koniczyny stanowią łatwe do rozpoznania (pod względem budowy morfologicznej) taksony o charakterystycznych liściach złożonych $z$ trzech odwrotnie jajowatych, zabkowanych listków (stąd wywodzi się łacińska nazwa: trifolium) oraz drobnych, motylkowych kwiatach, ściśle zebranych w główkowych kwiatostanach (Ryc. 1). Korona kwiatowa jest wyraźnie zróżnicowana jeśli chodzi o barwę. Przeważają gatunki posiadajace różowe, czerwone i purpurowe płatki korony, rzadziej zaś spotyka się koniczyny o białych lub żółtych kwiatach. Suche owoce (strąki) są bardzo drobne i mają w swoim wnętrzu zwykle po 1-2 nasiona (SABUDAK i GULER 2009, ZORIC i współaut. 2012).

\section{ZRÓŻNICOWANIE CHEMOTAKSONOMICZNE KONICZYN}

Mimo wyraźnych podobieństw morfologicznych, koniczyny charakteryzują się dużym zróżnicowaniem pod względem chemo- taksonomicznym. Najbardziej popularny w lecznictwie gatunek, koniczyna lakowa ( $T$. pratense L.), prezentuje profil składników polifenolowych, którego specyficzna cecha jest wysoka koncentracja związków izoflawonowych, w tym formononetyny i biochaniny A, oraz ich pochodnych glikozydowych (SABUDAK I GUler 2009, KAURINOVIC i współaut. 2012). Potwierdziły to także badania przeprowadzone w Katedrze i Zakładzie Farmakognozji z Pracownia Roślin Leczniczych Uniwersytetu Medycznego w Lublinie, w których ziele trzynastu gatunków koniczyn, występujących w naturalnych siedliskach na obszarze Polski, poddano analizie jakościowej i ilościowej pod kątem zawartości związków izoflawonowych o właściwościach estrogennych (ZGÓRKA 2011). Badania te potwierdziły, iż biochanina A i formononetyna oraz ich 7-O-glikozydy (sissotryna $i$ ononina) stanowia główne składniki frakcji izoflawonowej. Najwyższa średnią sumaryczna zawartość składników izoflawonowych, przekraczajaca 5\% suchej masy, stwierdzono w zielu koniczyny pogiętej (T. medium L.), łakkowej (T. pratense L.) i polnej (T. arvense L.), charakteryzujacych się barwa kwiatów od różowej do purpurowo-czerwonej. Wykazano wyraźne zróżnicowanie koncentracji oznaczanych izoflawonów w częściach nadziemnych badanych gatunków koniczyn i jego zwiazek $z$ zabarwieniem płatków korony u analizowanych taksonów. W przypadku żółto kwitnących gatunków koniczyn: złocistożółtej (T. aureum Pollich), drobnogłówkowej (T. dubium Sibthorp) i różnoogonkowej (T. campestre Schreber), wykazano bowiem wyrażną odrębność chemo- 

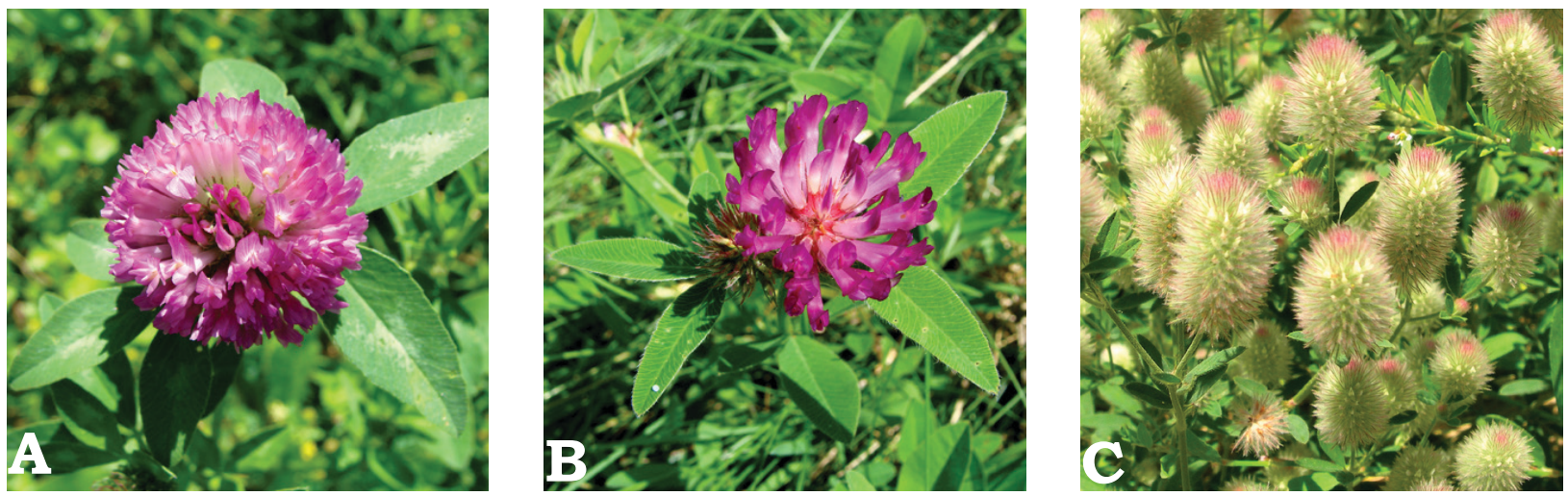

Ryc. 1. Badane gatunki koniczyn. A - koniczyna łąkowa (fot. G. Zgórka); B - koniczyna pogięta (fot. G. Zgórka); C - koniczyna polna (fot. P. Martyniuk).

taksonomiczna, polegająca na całkowitym braku w częściach nadziemnych estrogennie działajacych izoflawonów. Zidentyfikowano natomiast zwiazki flawonoidowe, $z$ grupy flawonów, co dowodzi całkowicie odmiennych właściwości biologicznych badanych gatunków koniczyn.

\section{KONICZYNY W ETNOMEDYCYNIE}

Liczne gatunki koniczyn, m.in. łakkowa (T. pratense L.), biała (T. repens L.), białoróżowa, zwana szwedzka (T. hybridum L.), czy inkarnatka (T. incarnatum L.) wykorzystuje się od stuleci jako rośliny pastewne. Wynika to $z$ ich wysokich walorów odżywczych, związanych $z$ dużą zawartościa metabolitów pierwotnych (zwłaszcza białek i cukrów), co stanowi charakterystyczna cechę wielu roślin motylkowych. Równocześnie, koniczyny towarzysza człowiekowi jako rośliny lecznicze, cenione od wieków za ich wielokierunkowe działanie w tradycyjnej medycynie wielu kultur. Przykładowo, w etnomedycynie europejskiej, ziele tych gatunków wykorzystywano m.in. w leczeniu dermatoz i stanów zapalnych oczu. Odwary $z$ koniczyn polecano także przy zapaleniu oskrzeli, przeziębieniach i grypie. W tradycyjnej medycynie tureckiej koniczyna łakowa, polna i biała znane były ze swoich właściwości analgetycznych, antyseptycznych, uspokajajacych czy wykrztuśnych. Ludność zamieszkująca tereny Syberii stosowała wodno-alkoholowe wyciągi $z$ kwiatów koniczyny białej (T. re pens L.) w leczeniu napadów epilepsji oraz w celu ograniczania rozwoju gruźlicy. Z kolei na zachodnim krańcu naszego kontynentu, w Portugalii, koniczyna wasskolistna ( $T$. angustifolium L.) była znanym panaceum na zaburzenia trawienne. Dla ludności Kosowa podobne wskazanie lecznicze miał sok wyciśnięty $\mathrm{z}$ liści koniczyny łąkowej. Ponadto, rdzenni mieszkańcy Ameryki Północnej (Indianie) wykorzystywali ziele tego gatunku do leczenia zmian skórnych, zaburzeń płodności i schorzeń o podłożu neurogennym (KOŁODZIEJCZYK-CZEPAS 2012, 2016).

\section{IZOFLAWONY - SKEADNIKI AKTYWNE KONICZYN}

Oprócz tradycyjnych zastosowań preparatów $z$ koniczyn, opartych na obserwacjach i długoletnim doświadczeniu, obecnie, jako roślinne produkty lecznicze, zatwierdzone przez Ministerstwo Zdrowia, wykorzystuje się ekstrakty $z$ ziela koniczyny łakkowej ze względu na ich działanie estrogenne oraz możliwość łagodzenia deficytów hormonalnych u kobiet w okresie około- i postmenopauzalnym. Aktywność tę dostrzeżono w początku ubiegłego wieku u zwierząt hodowlanych. Wyrażała się ona hiperestrogennymi zaburzeniami płodności u owiec, spowodowanymi spożyciem większych ilości koniczyny podziemnej (T. subterraneum L.). Jak się później okazało, za to działanie odpowiedzialne były związki izoflawonowe, które dopiero w latach 40. ubiegłego wieku wyodrębniono w stanie czystym (ADAMs i współaut. 1995).

Izoflawony klasyfikuje się jako barwniki roślinne (flawonoidy), które reprezentuja szersza grupę metabolitów wtórnych, należacych do fitopolifenoli, obejmujaca ponad 6500 związków (KOHLMÜNZER 2008). W zależności od typu budowy chemicznej, flawonoidy dzieli się na: flawony, flawonole, flawanony, dihydroflawonole, chalkony, aurony i izoflawony. Dane literaturowe wskazuja, że związki te w roślinach moga pełnić rolę fitoaleksyn, czyli substancji chemicznych wytwarzanych w odpowiedzi na uszkadzajace działanie różnorodnych patogenów (grzybów, owadów, itp.). Aktywność przeciwutleniajaca i fotoprotekcyjna flawonoidów zapewnia 
także roślinom ochronę przed szkodliwym promieniowaniem UV. Właściwości antyoksydacyjne i przeciwzapalne stanowia $z$ kolei podstawę wszechstronnej aktywności antybiodegeneracyjnej tych fitoskładników w organizmach zwierzęcych (SANDHAR i współaut. 2011, CORRADINI i współaut. 2011).

\section{DZIALANIE ESTROGENNE IZOFLAWONÓW}

Izoflawony stanowią szczególną klasę związków flawonoidowych, które ze względu na aktywność estrogenopodobna stały się obiektem wielu badań naukowych. Dane epidemiologiczne wskazuja na bezpośredni związek pomiędzy wysoką konsumpcją żywności bogatej w izoflawony a obserwowana, szczególnie w populacji azjatyckiej, niższą częstotliwością występowania hormonozależnych nowotworów, osteoporozy czy dolegliwości u kobiet zwiazanych $z$ niedomoga funkcji jajników (VILlASECA 2012). Aktywność estrogenna izoflawonów wynika $z$ podobieństwa ich struktury chemicznej do 17- $\beta$-estradiolu, co szczególnie widoczne jest w przypadku jednego $z$ głównych metabolitów - ekwolu (Ryc. 2). Odpowiednie ułożenie pierścieni fenylowych oraz zachowanie podobnej odległości pomiędzy skrajnymi podstawnikami hydroksylowymi zapewnia czasteczkom izoflawonów możliwość wpasowywania się w domenę wiążąca receptorów estrogenowych (ang. estrogen receptor, ER) (MOREIRA i współaut. 2014). Pomimo że siła wiąania izoflawonów $z$ ER jest znacznie mniejsza niż endogennych estrogenów, mogą one konkurować $z$ nimi o wiazanie $z$ ER, niwelujacc skutki deficytów estrogenowych u kobiet w okresie menopauzalnym. Ponadto, aktywacja ER indukuje w organizmach ssaków kaskadę czynników przeciwzapalnych i antyoksydacyjnych o działaniu cytoprotekcyjnym (GUZIK i współaut. 2014). Obecnie znane sa receptory estrogenowe typu a (ER-a) i $\beta$ (ER- $\beta)$. Istotnym faktem, w odniesieniu do potencjalnych zastosowań w profilaktyce i terapii jest to, że izoflawony przejawiają dominujacca aktywność w kierunku ER- $\beta$ (LAGARI i LEVIS 2010, VILLASECA 2012), wystepujacych obficie m.in. w tkance kostnej, ośrodkowym układzie nerwowym (OUN), układzie krażenia, gruczole krokowym, jądrach, jajnikach czy pęcherzu moczowym (JIA i współaut. 2015). Stopień powinowactwa do tych receptorów oraz ich niejednorodne rozmieszczenie w tkankach thumacza nieco odmienne działanie izoflawonów $\mathrm{w}$ porównaniu $\mathrm{z}$ syntetycznymi estrogenami stosowanymi m.in. w hormonalnej terapii zastepczej (HTZ) (PRAKASH i GUPTA 2014). Liczne badania in vivo ujawniły, że izoflawony działaja w sposób zbliżony do syntetycznych leków z grupy selektywnych modulatorów receptorów estrogenowych (SERMs), takich jak tamoksyfen czy raloksyfen, które stosuje się m.in. w hamowaniu rozwoju raka piersi oraz terapii osteoporozy (BECK i współaut. 2005, LAMAS i współaut. 2010, CHE i współaut. 2016). Jako SERMs, izoflawony moga wykazywać zarówno aktywność estrogenna, jak i antyestrogenna, niwelujac tym samym działania niepożądane endo- lub egzogennych estrogenów (VITALE i współaut. 2013, APARECIDA SANTOs i współaut. 2016).

\section{MIKROBIOM A BIODOSTEPNOŚĆ IZOFLAWONÓW}

Spośród izoflawonów zidentyfikowanych w roślinach największe zainteresowanie budza obecnie dwa związki: daidzeina i genisteina (Ryc. 2). Doniesienia naukowe $z$ badań in vitro i in vivo wskazuja na korzystne działanie obu tych fitoskładników w łagodzeniu skutków wielu schorzeń (osteoporozy, chorób sercowo-naczyniowych o podłożu miażdżycowym, depresji, zaburzeń libido, biodegeneracji układu rozrodczego $i$ innych), których etiologię wiąże się z występowaniem deficytów estrogenowych (GUERRERO i współaut. 2005, PILŠĂKOVĂ i współaut. 2010, SÁNCHEZ-CALVO i współaut. 2013, PAVESE i współaut. 2014). W roślinach, daidzeina i genisteina występują zarówno w postaci nieaktywnych form glikozydowych (daidzyny i genistyny), jak i metoksylowych

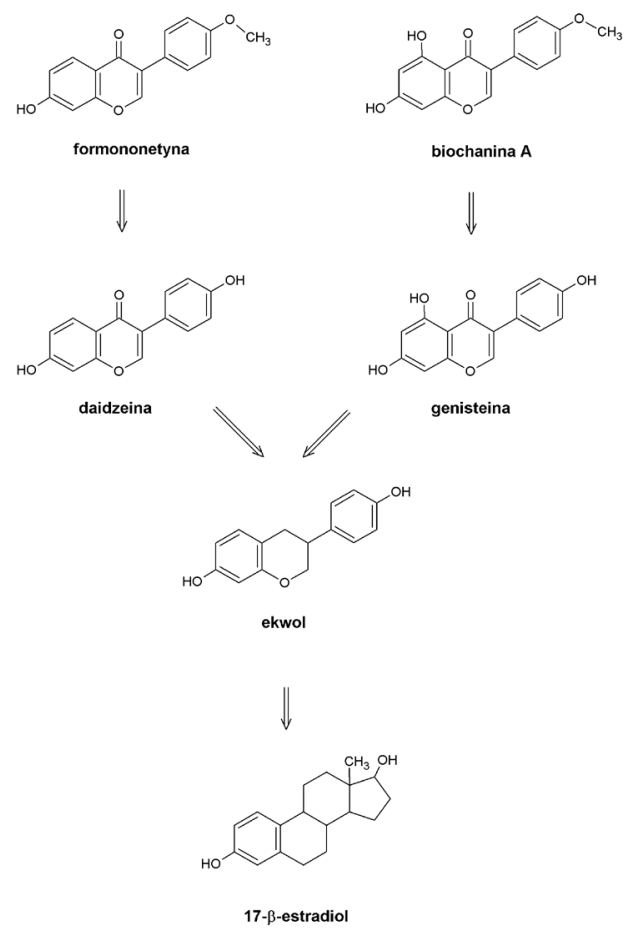

Ryc. 2. Szlak metaboliczny izoflawonów w organizmach ssaków. 
pochodnych: formononetyny i biochaniny A. Przy współudziale mikroflory jelitowej (mikrobiomu) ssaków, zwiazki te ulegaja transformacji metabolicznej do aktywnych biologicznie form aglikonowych (bezcukrowych), wykazujących jednocześnie wyższą biodostępność. W procesie dalszych przemian metabolicznych powstaje główny metabolit - ekwol - o 100-krotnie wyższej aktywności estrogennej $\mathrm{w}$ porównaniu $\mathrm{z}$ genisteina i daidzeiną (LAGARI i LEVIS 2014) (Ryc. 2). Dlatego, to głównie ekwol jest odpowiedzialny za większość efektów biologicznych przypisywanych izoflawonom. Zaobserwowane różnice $\mathrm{w}$ stężeniu tych związków w osoczu pacjentów przyjmujących preparaty izoflawonowe oraz efektywności ich działania w tkankach docelowych, sa zdeterminowane osobniczym zróżnicowaniem składu i zawartości mikroflory jelitowej. Jak wynika $z$ badań epidemiologicznych, skuteczność terapeutyczną izoflawonów warunkują m.in. takie czynniki jak: strefa geograficzna, w której bytuje dana populacja, stosowana dieta oraz zażywane leki, które moga ograniczać lub wspierać funkcję metaboliczna (aktywność enzymatyczna) mikrobiomu (BADOWSKI i URBANEK-KAREOWSKA 2001, LAGARI i LEVIS 2014). Istotną rolę odgrywaja także aspekty genetyczne. W każdej populacji istnieja bowiem osobniki o szczególnej predyspozycji do wytwarzania ekwolu, zarówno przy współudziale flory jelitowej, jak i w wyniku aktywowania szlaków metabolizmu wątrobowego (SÁNCHEZ-CALVO i współaut. 2013). Według niektórych autorów (DUDA-CHODAK i współaut. 2015), istotny wpływ na opisany powyżej proces ma dieta wzbogacona obecnościa polisacharydowych prebiotyków (np. inuliny), która może znacząco zwiększać aktywność enzymatyczna bakterii jelitowych. Interesujace wydaja się też doniesienia amerykańskich naukowców (GHAFAR i współaut. 2002), którzy wykazali wysoka skuteczność japońskiego produktu GCPTM (ang. Genistein Combined Polysaccharide), zawierającego w składzie (oprócz genisteiny) polisacharyd, otrzymany $\mathrm{z}$ grzybów należacych do gromady Basidiomycetes (podstawczaków). Produkt ten stosowano $u$ pacjentów $\mathrm{z}$ potwierdzonym (w wyniku biopsji) rakiem prostaty ze względu na możliwość ograniczania rozwoju tego nowotworu dzięki antyestrogennej aktywności metabolitów genisteiny (inhibicja szlaku aromatazy) w gruczole krokowym. Po okresie 6 tygodni, $\mathrm{u}$ chorych zaobserwowano spadek wartości specyficznego markeru PSA (ang. prostate-specific antigen) z 19,7 na 4,2 $\mathrm{ng} / \mathrm{mL}$. Po zabiegu prostatektomii, w usuniętych gruczołach nie stwierdzono obecności komórek nowotworowych.

\section{IZOFLAWONY JAKO NATURALNA ALTERNATYWA DLA HTZ}

Obecnie fitoestrogenoterapia stanowi realną alternatywę dla często kontrowersyjnej, ze względu na obserwowaną ilość działań niepożadanych, hormonalnej terapii zastępczej (IMHOF i współaut. 2006, Alves i współaut. 2008). Stosowanie produktów bogatych w składniki izoflawonowe oraz odpowiednio dobrana dieta umożliwiaja leczenie kobiet $z$ deficytami estrogenowymi, u których odnotowuje się m.in. współistniejące schorzenia watroby czy zaburzenia układu krzepnięcia, stanowiące przeciwwskazania do stosowania HTZ (LIPOVAC i współaut. 2011). Z tego względu obserwuje się rosnące zapotrzebowanie na produkty roślinne, łagodzace objawy neurowegetatywne i psychofizyczne, występujace u kobiet w okresie około- i postmenopauzalnym. Dotychczas role tę spełniały preparaty zawierające składniki izoflawonowe pozyskiwane $z$ nasion soi. Obecnie listę tego typu produktów uzupełniaja coraz częśsiej substancje pochodzenia roślinnego otrzymywane $z$ ziela koniczyny łakowej ( $T$. pratense L.), posiadające nieco inny profil składników izoflawonowych (dominacja ilościowa pochodnych biochaniny A i formononetyny). $\mathrm{Na}$ polskim rynku dostępne sa m.in. suplementy diety, takie jak: Femiflavon, Promensil forte, Mabelle, Minapent, Klimaktercaps czy Duo-Fem (DE LEMOS 2001, PILŠĂKOVÃ i współaut. 2010). Wielokierunkowe działanie farmakologiczne składników izoflawonowych, zawartych w zielu koniczyny łakowej, stwarza nadzieję na wykorzystanie ich $\mathrm{w}$ profilaktyce i terapii schorzeń biodegeneracyjnych. W opinii austriackich naukowców (DORNSTAUDER i współaut. 2001), standaryzowane wyciagi $\mathrm{z}$ ziela koniczyny łakkowej, zawierające składniki polifenolowe o wyższym powinowactwie do ER- $\beta$ niż do ER-a, moga stanowić bezpieczna alternatywę dla syntetycznych estrogenów stosowanych w HTZ u kobiet w okresie menopauzalnym. Zlewne poty, uderzenia goraca i schorzenia o podłożu neurogennym (depresje, zaburzenia snu), to jedne $z$ najczęściej obserwowanych objawów, wynikajacych $z$ niedomogi funkcji jajników (Guilliams 2001). Aktualnie prowadzone badania kliniczne wskazuja, że suplementacja diety izoflawonami koniczyny łakowej u kobiet po 50. roku prowadzi do zauważalnego łagodzenia typowych objawów menopauzalnych (LIPOVAC I WSPÓEAUT. 2011).

\section{FITOESTROGENY A OSTEOPOROZA}

Izoflawony koniczyn, wykazując dominująca aktywność wobec receptorów ER- $\beta$ w tkance kostnej, moga być także cennym 
środkiem w profilaktyce i terapii osteoporozy (TAM i współaut. 2012). Większość badań potwierdza pozytywna korelację pomię$\mathrm{dzy}$ spożywaniem produktów bogatych w fitoestrogeny, a gęstością mineralna tkanki kostnej (ang. bone mineral density, BMD). Dane literaturowe wskazuja na formononetynę jako główny składnik izoflawonowy koniczyny łąkowej, posiadajacy zdolność aktywacji komórek kościotwórczych (osteoblastów). W badaniach in vivo, zastosowanie tego izoflawonu w dawce $10 \mathrm{mg} / \mathrm{kg}$ m.c. (przez okres 12 tygodni), skutkowało zahamowaniem zmian degeneracyjnych w tkance kostnej (osteopenii) u szczurów (TYAGI i współaut. 2012) Suplementacja formononetyna wpłynęła m.in. na poprawę właściwości mechanicznych kości, a także ich zwiększona mineralizację (KACZMARCZYK-SEDLAK i współaut. 2013). Inny składnik izoflawonowy ziela koniczyny łąkowej, biochanina A, może również wywierać korzystne efekty w układzie kostnym. W testach in vitro, przeprowadzonych przez Su i współaut. (2013), odnotowano zmniejszanie aktywności komórek kościogubnych (osteoklastów) oraz zwiększanie procesów regeneracyjnych tkanki kostnej $z$ udziałem osteoblastów. Zastosowanie ekstraktów $z$ ziela koniczyny łąkowej (T. pratense L.) i koniczyny pogiętej (T. medium L.) w badaniach in vivo ujawniło również pozytywny wpływ badanych ekstraktów na układ kostny zwierzat. Aby odzwierciedlić stan, jaki występuje u kobiet w okresie menopauzy, posłużono się modelem sztucznie wywołanej osteoporozy u samic szczurów, u których owariektomia (usunięcie jajników) spowodowała trwały niedobór estrogenów $z$ następczym zrzeszotnieniem kości. W badaniach zastosowano dawki 10 i $20 \mathrm{mg} / \mathrm{kg} \mathrm{m.c.} \mathrm{zespołu} \mathrm{izoflawonów,} \mathrm{cze-}$ go rezultatem była poprawa parametrów histomorfometrycznych oraz mechanicznych kości. Oba ekstrakty w znaczacy sposób zwiększały odporność mechaniczna trzonu kości udowej. Dodatkowo stwierdzono, że ich zastosowanie stymulowało mineralizację tkanki kostnej, co przejawiało się wzrostem zawartości fosforu i wapnia w kościach piszczelowych oraz w kregach L-4 owariektomizowanych samic szczurów (CEGIEŁA i współaut. 2012).

\section{NOWE TRENDY W TERAPII RAKA GRUCZOEU KROKOWEGO}

Ze względu na równolegle wykazywaną aktywność estrogenna i antyestrogenną, izoflawony koniczyn budzą zainteresowanie naukowców jako fitoskładniki o aktywności cytostatycznej, możliwej do wykorzystania we wspomagajacej terapii nowotworów hor- monozależnych, m.in. raka piersi czy gruczołu krokowego. W ostatnich dwóch dekadach obserwuje się wyraźny wzrost badań in vitro $\mathrm{i}$ in vivo, analizujacych działanie antyneoplastyczne tych związków. W przypadku raka prostaty, aktywność ta wiąże się nie tylko $z$ selektywnym oddziaływaniem na receptory ER- $\beta$, występujace $w$ gruczole krokowym, ale także ze zdolnością do zwiększania stężenia globuliny wiążacej hormony płciowe (SHBG) w osoczu krwi. Ograniczając biodostępność endogennych estrogenów, izoflawony przyczyniaja się do skrócenia czasu ekspozycji komórek gruczołu na ich negatywne działanie (Wu i współaut. 1998, PINO i współaut. 2000, ViJ i Kumar 2004). Ponadto, istotne znaczenie moga mieć również efekty pozaestrogenowe wykazywane przez związki izoflawonowe. Badania na liniach komórkowych potwierdzaja ich zdolność do modulowania cyklu komórkowego i procesu apoptozy. W tkankach obwodowych, izoflawony hamujac aktywność szeregu enzymów uczestniczących w procesach proliferacji komórek, takich jak kinaza tyrozynowa czy topoizomeraza II, oraz ograniczaja proces angiogenezy (MAHMOUD i współaut. 2014, ZHANG i współaut. 2016). Badania in vitro na liniach komórkowych raka gruczołu krokowego wykazały, iż dawka 100 nM izoflawonów koniczyny łąkowej hamowała aktywność transformującego czynnika wzrostu $\beta 1$ (TGF- $\beta 1$ ), odpowiedzialnego za przekształcenie dehydroepiandosteronu do androgenów i proliferację komórek gruczołu oraz zmniejszała koncentrację specyficznego antygenu sterczowego (PSA), będącego markerem osoczowym, wykorzystywanym w diagnostyce i monitorowaniu procesów rozrostowych i/lub nowotworowych w gruczole krokowym (HEDLUND i współaut. 2003, LIU i współaut. 2011). Efekt ochronny izoflawonów może także wynikać ze zdolności hamowania produkcji androgenów wskutek inhibicji 5-a-reduktazy. Enzym ten uczestniczy w przemianie testosteronu do dihydrotestosteronu (DHT), będącego znanym czynnikiem prorozrostowym w gruczole krokowym. W przeciwieństwie do populacji mężczyzn społeczeństw zachodnich, zapadalność na raka prostaty jest znacznie niższa u przedstawicieli rasy żółtej. Dane epidemiologiczne potwierdzaja odwrotna zależność pomiędzy spożyciem produktów zawierających izoflawony, a poziomem DHT, który jest niższy u Azjatów. Udokumentowano także, że genisteina, biochanina A i ekwol, podawane w stężeniu (100 $\mu \mathrm{mol} / 1)$, wykazują zdolność do zmniejszenia aktywności 5-a-reduktazy nawet o 80\% (THAM i współaut. 1998). 


\section{PODSUMOWANIE}

Liczne badania epidemiologiczne, potwierdzające istnienie zależności pomiędzy zmniejszona zapadalnościa na choroby biodegeneracyjne, a zwiększona podaża produktów sojowych, bogatych w składniki izoflawonowe, stały się powodem szerszego zainteresowania ta grupa roślinnych metabolitów wtórnych z grupy fitoestrogenów. W ostatnich dwóch dekadach, coraz większe znaczenie, jako nowe źródło izoflawonów, zyskuja gatunki czerwono i różowo kwitnących koniczyn, w tym koniczyna łakowa (T. pratense L.), koniczyna pogięta (T. medium L.) i koniczyna polna ( $T$. arvense L.). Aktywne metabolity izoflawonów koniczyn (ekwol) wykazuja zdolność selektywnej modulacji receptorów estrogenowych, dzięki czemu wymienione taksony moga być wykorzystywane $\mathrm{w}$ hamowaniu różnorodnych procesów biodegeneracyjnych, spowodowanych deficytami hormonalnymi. Najnowsze badania naukowe wskazuja na możliwość zastosowania izoflawonów koniczyn nie tylko u kobiet w okresie około- i postmenopauzalnym (np. jako alternatywa dla HTZ), ale także u mężczyzn, we wspomagającej terapii raka gruczołu krokowego.

\section{Streszczenie}

Gatunki należące do rodzaju Trifolium L. (koniczyna), wykorzystywane od wieków w etnomedycynie, stanowią dziś bogate źródło fitohormonów polifenolowych. $\mathrm{W}$ badaniach chemotaksonomicznych udokumentowano bowiem, że czerwono kwitnące koniczyny odznaczaja się szczególnie wysoką zawartością izoflawonów. Związki te posiadaja aktywność estrogenopodobna, dlatego moga działać analogicznie do selektywnych modulatorów receptorów estrogenowych (SERMs). Dane epidemiologiczne oraz liczne doniesienia $z$ badań przedklinicznych i klinicznych dowodzą korzystnego działania tych fitoskładników zarówno w łagodzeniu wielu psychicznych i neurowegetatywnych dolegliwości, wystepujacych w okresie menopauzy, jak i możliwości prewencji i terapii schorzeń biodegeneracyjnych, będacych skutkiem deficytów estrogenowych (osteoporoza, miażdżyca). W nieodległej przyszłości, moga również pojawić się nowe zastosowania dla izoflawonów koniczyn w zakresie zwalczania niektórych typów schorzeń nowotworowych. Ze względu na nieliczne obserwowane działania niepożądane, fitoestrogeny występujace w rodzaju Trifolium L. traktowane sa jako alternatywa nie tylko dla popularnych produktów sojowych, ale i syntetycznych estrogenomimetyków, wykorzystywanych w hormonalnej terapii zastępczej (HTZ).

\section{LITERATURA}

ADAMS N. R., 1995. Detection of the effects of phytoestrogens on sheep and cattle. J. Animal. Sci. 73, 1509-1515.

Alves D. L., Lima S. M. R. R., Da Silva C. R., LONGo Galvăo M. A., Shanaider A., DE ALMEIDA PRADO R. A., AOKI T., 2008. Effects of Trifolium pratense and Cimicifuga racemosa on the endometrium of wistar rats. Maturitas $61,364-370$.
Aparecida SANTOS M., Florencio-Silva R., TEIXEIRA C. P., Rodrigues DA Silva SASSO G., SOUZA Marinho D., Simões R. S., SimÕes M. J., FERRAZ CARBONEL A., 2016. Effects of early and late treatment with soy isoflavones in the mammary gland of ovariectomized rats. Climacteric 19, 77-84.

Badowski P., URbaneK-KarŁowska B., 2001. Phytoestrogens in foods - a review. Rocz. Państw. Zakł. Hig. 52, 203-212.

Beck V., ROHR U., Jungbauer A., 2005. Phytoestrogens derived from red clover: An alternative to estrogen replacement therapy? J. Steroid. Biochem. Mol. Biol. 94, 499-518.

CEgIEEA U., FOLWARCZNA J., PYTLIK M., ZGÓRKA G., 2012. Effects of extracts from Trifolium medium L. and Trifolium pratense L. on development of estrogen deficiency-induced osteoporosis in rats. Evid. Based Complement. Alternat. Med. 2012, doi: 10.1155/2012/921684.

Che C. T., Wong M. S., LAM C. W. K., 2016. Natural products from Chinese medicines with potential benefits to bone health. Molecules $21,239$.

CorRadini E., Foglia P., Giansanti P., GuBbiotti R., SAMPERI R., LAGANÀ A., 2011. Flavonoids: chemical properties and analytical methodologies of identification and quantitation in foods and plants. Nat. Prod. Res. 25, 469-495.

DE LEMOS M. L., 2001. Effects of soy phytoestrogens genistein and daidzein on breast cancer growth. Ann. Pharmacother. 35, 1118-1121.

DORNSTAUDER E., JiSA E., UNTERRIEDER I., KRENN L., Kubelka W., JungBaUeR A., 2001. Estrogenic activity of two standardized red clover extracts (Menoflavon ${ }^{\circledR}$ ) intended for large scale use in hormone replacement therapy. J. Ster. Biochem. Mol. Biol. 78, 67-75.

DUDA-CHODAK A., TARKO T., SATORA P., SROKA P., 2015. Interaction of dietary compounds, especially polyphenols, with the intestinal microbiota: a review. Eur. J. Nutr. 54, 325.

GHAFAR M. A., GOlliday E., Bingham J., MANSUKHANI M. M., ANASTASIADIS A. G., KatZ A. E., 2002. Regression of prostate cancer follow ing administration of genistein combined poly saccharide (GCPTM), a nutritional supplement: A case report. J. Alter. Compl. Med. 8, 493497.

Guerrero J. A., lozano M. L., Castillo J., BeNAVENTE-GARCíA O., VicENTE V., RIVERA J., 2005. Flavonoids inhibit platelet function through binding to the thromboxane $A_{2}$ receptor. J. Thromb. Haem. 3, 369-376.

Guilliams T. G., 2001. Menopause - A Natural Transition. Standard 4, 1-12.

GuziK A., SAwicka E., DŁUgosz A., 2014. Rola estrogenów i czynników środowiskowych $w$ raku prostaty. Bromat. Chem. Toksykol. 1, 57-63

Hedlund T. E., Johannes W. U., Miller G. J., 2003. Soy isoflavonoid equol modulates the growth of benign and malignant prostatic epithelial cells in vitro. Prostate 54, 68-78.

Imhof M., GOCAN A., REITHMAYR F., M. LIPOVAC M., SChimitzeK C., Chedraui P., Huber J., 2006. Effects of a red clover extract (MF11RCE) on endometrium and sex hormones in postmenopausal women. Maturitas 55, 76-81.

JiA M., DAHLMAN-WRIGHT K., GUSTAFSSON J. A., 2015. Estrogen receptor alpha and beta in health and disease. Best Pract. Res. Cl. En. 29, 557-568.

KACZMARCZYK-SEDLAK I., WOJNAR W., ZYCH M., OZIMINA-KAMIŃSKA M., TARANOWICZ J., SiWEK A., 2013. Effect of formononetin on mechanical properties and chemical composition of 
bones in rats with ovariectomy-induced osteoporosis. Evid. Based Compl. Alter. Med., doi. org/10.1155/2013/457052

KAURINOVIC B., POPOVIC M., VlaisaVlJEVIC S. SCHWARTSOVA H., VOJINOVIC-MILORADOV M., 2012. Antioxidant profile of Trifolium pratense L. Molecules 17, 11156-11172.

KOHLMÜNZER S., 2008. Farmakognozja. PZWL, Warszawa.

KoŁODZIEJCZYK-CZEPAS J., 2012. Trifolium species-derived substances and extracts - biological activity and prospects for medicinal applications. J. Ethnopharmacol. 143, 14-23.

KoŁODZIEJCZYK-CZEPAS J., 2016. Trifolium species - the latest findings on chemical profile, ethnomedicinal use and pharmacological properties. J. Pharm. Pharmacol. 68, 845-861.

LAGARI V. S., LEVIS S., 2010. Phytoestrogens and bone health. Curr. Opin. Endocrinol. Diabetes Obes. 17, 546-553.

LAGARI V. S., LEVIS S., 2014. Phytoestrogens for menopausal bone loss and climacteric symptoms. J. Steroid Biochem. 139, 294-301.

Lamas A. Z., NAScimento A. M., Medeiros A. R. S., Caliman I. F., Dalpiaz P. L. M., Firmes L. B., Sousa G. J., Oliveira P. W. C., Andrade T. U., REIS A. M., GouveA S. A., BISSOlI N. S., 2010. The Selective Estrogen Receptor Modulators (SERMs) Raloxifene and Tamoxifen improve ANP levels and decrease nuclear translocation of $N F-k B$ in estrogen-deficient rats. Pharmacol. Rep. 69, 798-805.

Lipovac M., Chedraui P., GRUenhut Ch., Gocan A., KurZ CH., Neuber B., IMHOF M., 2011. Effect of red clover isoflavones over skin, appendages, and mucosal status in postmenopausal women. Obst. Gynecol. Int. 2011, doi: 10.1155/2011/949302.

LIU X., PIAO Y. S., ARNOLD J. T., 2011. Transforming growth factor $\beta 1$ increase of hydroxysteroid dehydrogenase proteins is partly suppressed by red clover isoflavones in human primary prostate cancer-derived stromal cells. Carcinogenesis 32, 1648-1654.

Mahmoud A. M., YANG W. Bosland M. C., 2014. Soy isoflavones and prostate cancer: a review of molecular mechanisms. J. Steroid. Biochem. Mol. Biol. 140, 116-132.

Moreira A. C., Silva A. M., SAnTos M. S., SARDÃO V. A., 2014. Phytoestrogens as alternative hormone replacement therapy in menopause: What is real, what is unknown. J. Steroid Biochem. 143, 61-71.

Pavese J. M., Krishna S. N., Bergan R. C., 2014. Genistein inhibits human prostate cancer cell detachment, invasion, and metastasis. Am. J. Clin. Nutr. 100, 431S-436S.

PILŠĂKOVĂ L., RIEČANSKŶY I., JAGLA F., 2010. The physiological actions of isoflavone phytoestrogens. Phytother. Res. 59, 651-664

Pino A. M., Valladares L. E., Palma M. A., ManCIlla A. M., YÁÑEZ M., Albala C., 2000. Dietary isoflavones affect sex hormone-binding globulin levels in postmenopausal women. J. Clin. Endocrinol. Metab. 85, 2797-2800.

PRAKASH D., GUPTA CH., 2014. Role of phytoestrogens as nutraceuticals in human health [W:] Phytochemicals of nutraceutical importance.
PRAKASH D., SHARMA G. (red.) CABI International, Boston, 148-149.

SABUDAK T., GULER N., 2009. Trifolium L. - a review on its phytochemical and pharmacological profile. Phytother. Res. 23, 439-446.

SÁNCHEZ-CALVO J. M., RoDRígUEZ-IGLESIAS M. A., Molinillo J. M., MaCíAS F. A., 2013. Soy isoflavones and their relationship with microflora: beneficial effects on human health in equol producers. Phytochem. Rev. 12, 979-1000.

SANDHAR H. K., KUMAR B., PRASHER S., TIWARI P., SAlHAN M., ShaRma P., 2011. A review of phytochemistry and pharmacology of flavonoids. Int. Pharm. Sci. 1, 25-38.

Su S. J., YEH Y. T., SHYU H. W., 2013. The preventive effect of biochanin $A$ on bone loss in ovariectomized rats: involvement in regulation of growth and activity of osteoblasts and osteoclasts. Evid. Based Compl. Alter. Med.

TAM Y. K., LiN Y. J., SlOleY B. D., TSENG C., 2012. Development of a phytoestrogen product for the prevention or treatment of osteoporosis using red clover. U.S. Patent Application No. 13/251, 267.

Tham D. M., Christopher D. G., Haskell W. L., 1998. Potential health benefits of dietary phytoestrogens: a review of the clinical epidemiological, and mechanistic evidence. J. Clin. Endocrinol. Metabo. 83, 2223-2235.

Tyagi A. M., SRIVAstava K., Singh A. K., Kumar A., ChangKiJA B., PANDEY R., LAHIRI S., NAGAR G. K., YADAV D. K., MAURYA R., TRIVEDI R., SinGH D., 2012. Formononetin reverses established osteopenia in adult ovariectomized rats. Menopause 8, 856-63.

VIJ U., KUMAR A., 2004. Phytoestrogens and prostatic growth. Nat. Med. J. India. 17, 22-26.

VILlaseCA P., 2012. Non-estrogen conventional and phytochemical treatments for vasomotor symptoms: what needs to be known for practice. Climacteric 15, 115-124.

Vitale D. C., Piazza C., Melilli B., Drago F., SAlOMONE S., 2013. Isoflavones: estrogenic activity, biological effect and bioavailability. Eur. J. Drug Metab. Pharmacokinet. 38, 15-25.

Wu A. H., ZIElgler R. G., NOMURA A. M., 1998. Soy intake and risk of breast cancer in Asians and Asians Americans. Am. J. Clin. Nutr. 68, 1437S-1443S

ZGÓRKA G., 2011. Studies on phytoestrogenic and nonphytoestrogenic compounds in Trifolium incarnatum L. and other clover species using pressurized liquid extraction and high performance column liquid chromatography with photodiode-array and fluorescence detection. J. AOAC Int. 94, 22-31.

ZhaNG H. Y., CUI J., ZHANG Y., Wang Z. L., CHONG T., WANG Z. M., 2016. Isoflavones and prostate cancer: A review of some critical issues. Chin. Med. J., 129, 341.

ZORIC L., MERKULOV L., LUKOVIC J., BOZA P., 2012. Comparative analysis of qualitative anatomical characters of Trifolium L. (Fabaceae) and their taxonomic implications: preliminary results. Plant Syst. Evol. 298, 205-219. 
KOSMOS Vol. 67, 3, 635-642, 2018

\author{
Magdalena Maciejewska, GraŻyna ZGóRKa
}

Chair and Department of Pharmacognosy with Medicinal Plant Unit, Medical University of Lublin, 1 Chodźki Str., 20-093 Lublin, E-mail: magdalena.maciejewska@umlub.pl,gzgorka@pharmacognosy.org

\title{
TRIFOLIUM L. (CLOVER) GENUS AS A NEW SOURCE OF PHYTOCONSTITUENTS WITH ANTIBIODEGENERATIVE PROPERTIES
}

\section{Summary}

Species belonging to the Trifolium L. (clover) genus, used for centuries in ethnomedicine, nowadays constitute a rich source of polyphenolic phytohormones. Chemotaxonomic studies revealed that red-blooming clovers are characterized by a particularly high content of isoflavones. These compounds have estrogen-like activity, therefore they can act like selective estrogen receptor modulators (SERMs). Both epidemiological, preclinical and clinical studies prove their beneficial effects in alleviating numerous mental and neurovegetative symptoms occurring during menopause, as well as in the prevention and treatment of biodegenerative diseases resulting from estrogen deficiency (osteoporosis, atherosclerosis). In the near future, new uses for clover isoflavones may also appear in the fight against some types of neoplastic diseases. Due to the small number of side effects, phytoestrogens occurring in the Trifolium L. genus are considered as an alternative not only to popular soybean products but also to synthetic estrogen mimetics used in hormone replacement therapy (HRT).

Key words: andropause, isoflavones, menopause, phytoestrogens, Trifolium L. (clover) genus 